\title{
CRIONIVAL PROCESSES AND THEIR EFFECT ON THE TYPES OF AGRICULTURAL LAND USE IN SILVANIA MOUNTAINS
}

\author{
CORINA BOGDAN¹, IOAN AUREL IRIMUȘ1
}

\begin{abstract}
Crionival Processes and Their Effect on the Types of Agricultural Land Use in Silvania Mountains. Silvania Mountains are a particular geospatial entity within the geomorphological landscape of Silvania, bringing together Plopiș Mountains (Măgura Mare Peak $917 \mathrm{~m}$ ) and Meseș Mountains (Măgura Pria Peak 996 m) and only comparatively Măgura Şimleului (597m) and Măgura Chilioarei (420 m), taking into account their high degree of erosion, into one family of mountains, forming a boundary of the vast Neogene Simleu gulf from West to East and North-East. Between the 15th and 19th centuries, the so-called Little Ice Age (LIA) was documented for the Northern Hemisphere and in particular for the Silvania Mountains and the surrounding areas (Bihor Mountains) through the identification of fossils belonging to some buffalos, which died during the LIA. The effects of crionival processes on the types of agricultural land use in Silvania Mountains are manifested through freeze-thaw phenomena and small avalanches in close interrelationship with the climate factor and conditions offered by the adjacent Silvania sublayer.
\end{abstract}

Keywords: Alpine collisional chain, Little Ice Age LIA, crionival processes, avalanches, Silvania Mountains.

\section{INTRODUCTION}

The Silvania Mountains, as an Alpine collisional chain (see fig. 1, 2), represent a fascinating and controversial geomorphological entity, formed during the Hercynian and Alpine thermo-tectonic cycles, on different levels of integration. Thus, one can identify in their structure the marks of a "Hercynian paleomorphology" in the shape of Varistic remnants incorporated in the structures of alpine nappes of the Apusenides, characterized by an eclogite metamorphism of Varistic age, later involved in the Alpine thermotectonic cycle. Nowadays it is

\footnotetext{
${ }^{1}$ Babeș-Bolyai University, Doctoral School of Geography, 5-7 Clinicilor Street, Cluj-Napoca, Romania,e-mails: bogdan.corina@ymail.com; aurel.irimus@ubbcluj.ro.
} 
represented by some islands of crystalline schists in the north-western part of the Transylvanian Depression, in the area occupied by Șimleu Basin / Cretaceous Belt of the Silvania Mountain from a geological point of view and by the IntraCarpathian Yoke from a geographical perspective.

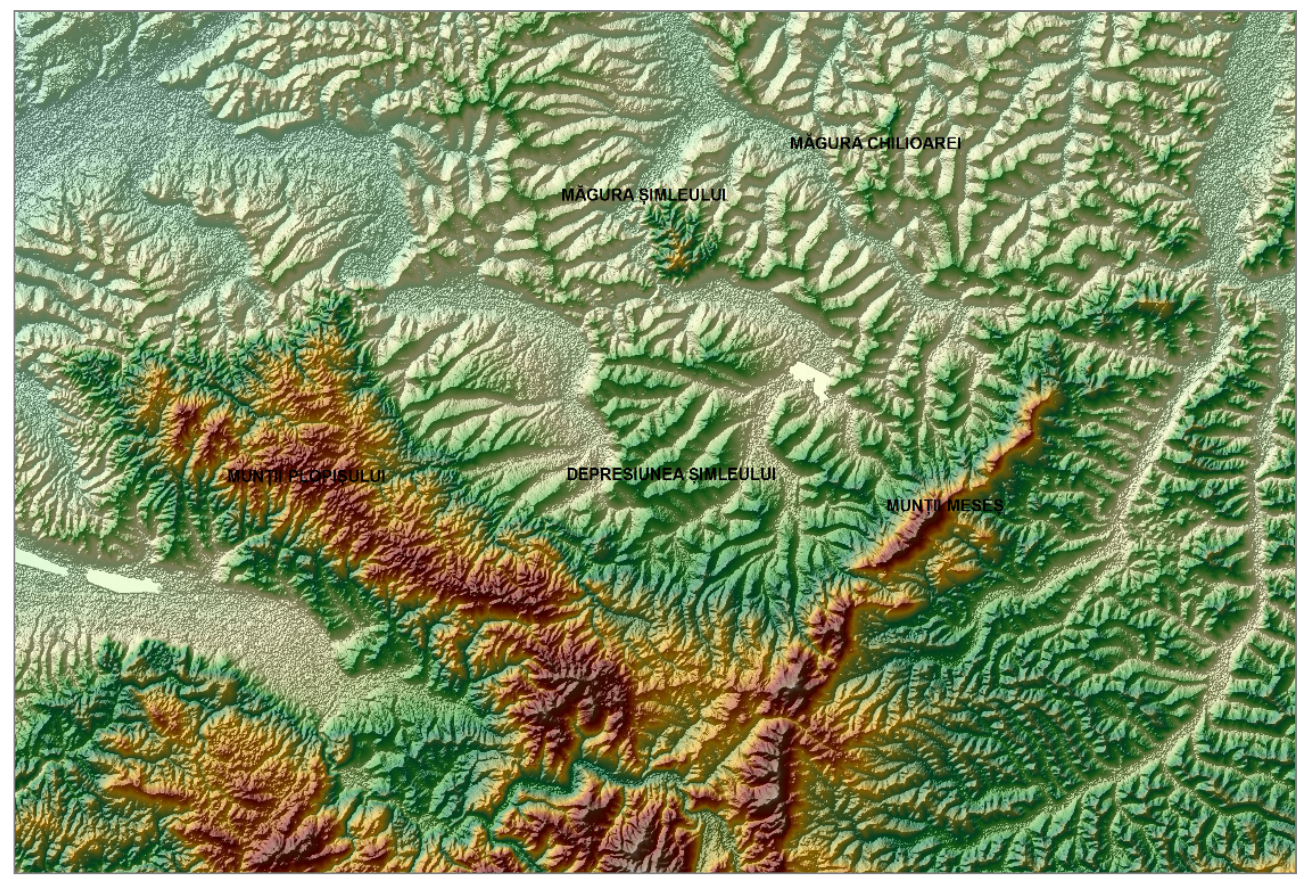

Fig. 1. DEM model of Silvania Mountains and their surrounding areas (Source: the authors)

From a geological and structural point of view, the studied area overlaps the Simleu Basin, one of the five basins or Neogene gulfs formed through the collapse of the crystalline basement of the Tisia Craton, in the peripheral area of the Apuseni Mountains, located in the immediate vicinity of the Pannonian Depression. The continental climate changes and the marks of human activities on the environment during the Holocene were generally identified through records of sediments on long term, ice cores and peat which, when they are available, present a less disturbed stratigraphy of the oligoelements. The duration and the regional or global extension of these natural and anthropogenic disturbances are analyzed through a multi-proxy approach. 
Therefore the combination between the stratigraphy with high resolution and biogeochemical markers emphasize the characterization of "abrupt climate change" when some limit thresholds are exceeded in duration and intensity (Alley et al., 2003; Clark et al.,2002; Trenberth, 1997, Trenberth et al., 2004). We quote one of the most intense climate crisis during the Upper Pleistocene, respectively the cold event "Younger Dryas (YD)", which took place between 13.0 and $11.5 \mathrm{kyr}$ $\mathrm{BP}$, and has been expanded into continental Europe, implicitly the Romanian Carpathians and the Silvania Mountains (Alley et al., Broecker, 2003, Clark et al., 2001, 2002; Dansgaard et al., 1989, Peteet, 1992, 1995, Severinghaus and Brok, 1999, Wright,1998, Wunsch, 2006).

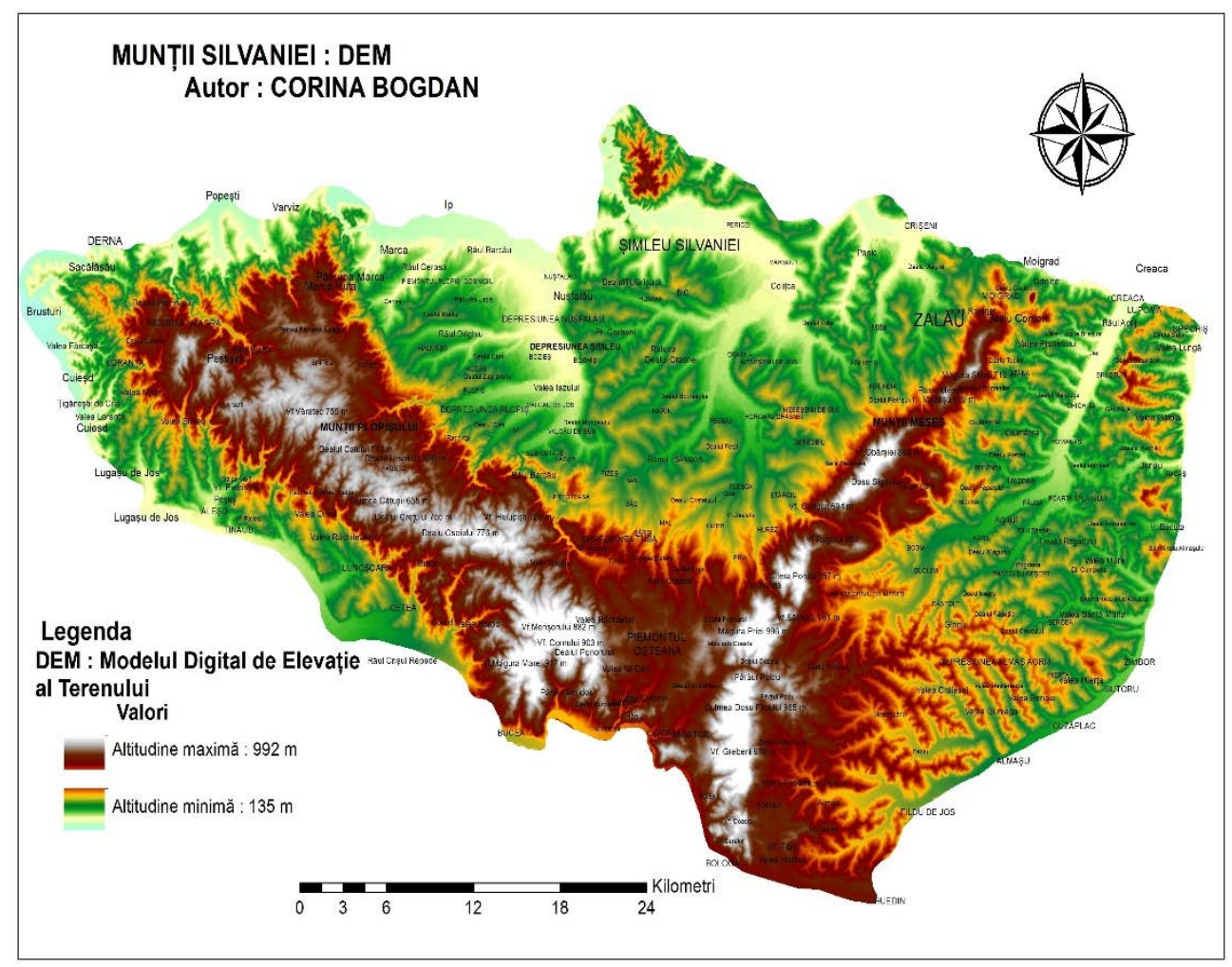

Fig. 2. DEM model of Silvania Mountains (Source: the authors)

The crisis was triggered by the discharge of melted water of Laurentide ice blocks, an event that led to the partial closure of the meridional circulation of restraint (MOC, Hughen et al., 1998; Paasche, 2006, Muscheler et al., 2000) 
which substantially controlled the balance of thermal masses from North Atlantic regions (Bond et al., 1997; Broecker, 2003; Broecker and Denton, 1989; Fairbanks, 1989; Keygwin et al., 1991; Lehman et al., 1991). The reconstruction of climate variability over the past millennium provides important perspectives for the understanding of current climate change.

It is difficult to rebuild the past hydrological changes because rainfall and its variability is among the most critical environment variables. The multiproxy analysis in northern Romania, in Rodna Range (based on plant macrofossils, carbon isotopes, pollen, spores and coal), led to the identification by A. Feurdean et al. (2015) of 5 main stages in relation to hydro-climatic conditions changes (conditions of growth/development of the wet surface between 800-1150 AD, respectively 1800 and $1950 \mathrm{AD}$, the drying of mud surface between 1300-1450 AD; $1550 \mathrm{AD} ; 1750$ and $2012 \mathrm{AD}$ ). The multi-proxy reconstructions performed by the authors suggest that during the "Medieval Climatic Anomaly" (900-1150 AD) they were considerably moister than at present, while during the Little Ice Age (LIA, 1500-1850 AD) they were dried. Comparatively, in Silvania Mountains, the areas have dried considerably over the past 40 years, as a result of climate change induced especially by anthropogenic activities; therefore we have the driest conditions observed during the past 1000 years.

The approach of crionival processes and their effects on the types of agricultural use of land imposes some introductory concepts in relation to the term periglacial which was initially proposed to indicate the geomorphological processes that took place in a peripheral strip in the external areas close to the glacial calottes.

Subsequently, the term has acquired a wider significance being used to indicate the different geomorphological phenomena specific to cold climates, in the external part of the limit of permanent snow, where the snow melts completely during summer and alternations of freeze-thaw cycles take place, which is the main and most important morphogenetic process. The term "periglacial" passes from the areal meaning (peri-glacial, near the glaciers) to only its climatic, inexact meaning. Other terms were introduced: crionival, paraglacial, arctic, but we will plead for the term periglacial (Panizza, 2007). Why these clarifications? Because both terms, periglacial and crionival, have a certain degree of ambiguity but ultimately have the same semantic meaning.

The mountainous area within Plopiş and Meseş Mountains, Măgura Şimleului and Măgura Coşeiului, in the cold seasons and especially during the Little Ice Age LIA, was submitted to the alternation of freeze-thaw cycles which acted upon the landscape through the creation of a series of processes and typical erosion and accumulation landforms. Most forms and periglacial deposits in 
Romania belong to the Würm, due to the existence of a bi- or multiannual gelisol, whose limit lies in the exterior of the Carpathians. In terms of zonation, there are three provinces: a central one, with gelisol and intense periglacial processes and two external ones, without the presence of gelisol while crionival processes only developed during a large part of the year.
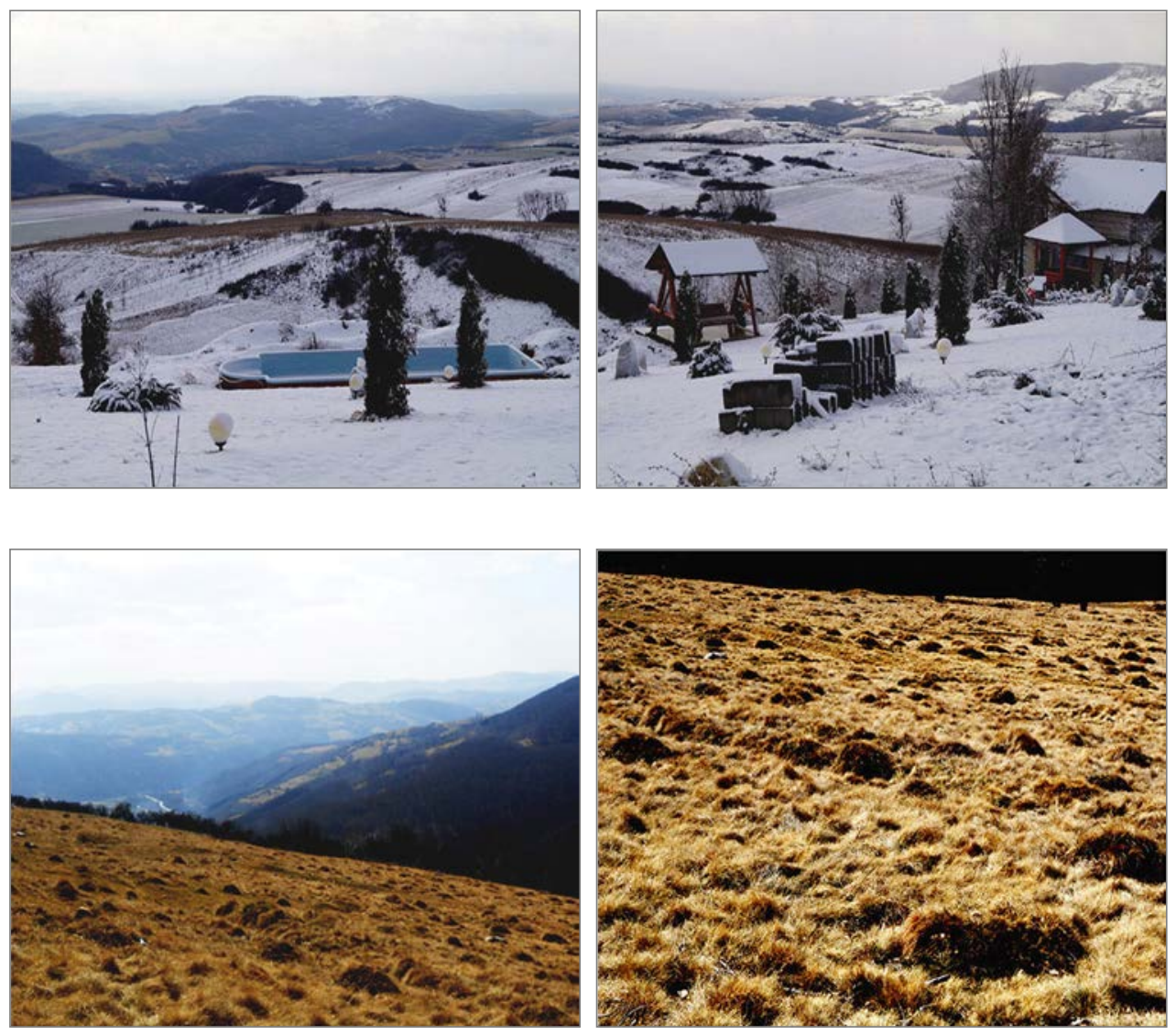

Fig. 3. Cryoplanation forms in Meseş Mountains (upper row) and grassed hills in Plopiş Mountains, Ponor Karst Plateau

(source: the author)

During the cold climate stages, outside the level affected by glaciation processes, the modeling took place under the impulse of the periglacial processes, gelivation and nivation, having a different role according to the topoclimatic conditions related to the Silvania area (fig. 3). 


\section{MATERIALS AND METHODS}

Regarding the materials, the methodology and the techniques used for outlining the crionival processes and their effects on the types of agricultural land use in Silvania Mountains, we took into account the topographic and geological databases, and used the geomorphological mapping techniques. In this respect, we transposed to the topographic map the morphology of these contemporary geomorphological processes as a reflex of a complex interaction between the crystalline bedrock, the sedimentary cover and the internal and external geodynamic agents. The geomorphological map was created using a methodology of the Italian school of geomorphology (fig. 5). Thus, using the related topographic and geological base, we mapped and represented cartographically both the lithology of the bedrock and the main endogenous and exogenous processes, specific to the Silvania Mountains. The main difference lies in the fact that the topographic base is also visible on the final geomorphological map, confirming the dynamics and the evolution of processes in the Silvania Mountains. In terms of methods and techniques, we used the cartographic method and the GIS analysis. We structured this paper into three parts, related to crionival processes in Silvania area, the areal distribution of land use classes and the effects of crionival processes on the types of agricultural land use in Silvania Mountains.

\section{CRIONIVAL PROCESSES IN THE SILVANIA AREA}

From the point of view of the periglacial processes, Silvania Mountains have common characteristics with the Transylvanian region, with a development of the detritic perigacial layer and a predominance of the crionival sublayer. In this respect, we have identified residual landforms and accumulation forms within Silvania Mountains.

\subsection{Residual landforms}

These are forms arising from periglacial modeling of the type of ice wedges, involutions and false folds (cryoturbation). The inherited periglacial landscape of Silvania Mountains is integrated into the evolution of the Northern Central, Transylvanian and Western periglacial provinces. The Transylvanian Basin and Șimleu Basin, due to their geographical position, allowed the stagnation and the maintenance of cold air masses, with North-Western influences, that created favourable conditions for the triggering of some intense crionival processes (fig. 3). The periglacial morphology of Silvania area is the result of freeze-thaw exogenous 
processes, whose interaction with the Silvania bedrock formed a product of synthesis, in this case an "obvious relict permafrost" as a reflex of the previous periglacial modeling of these mountains.
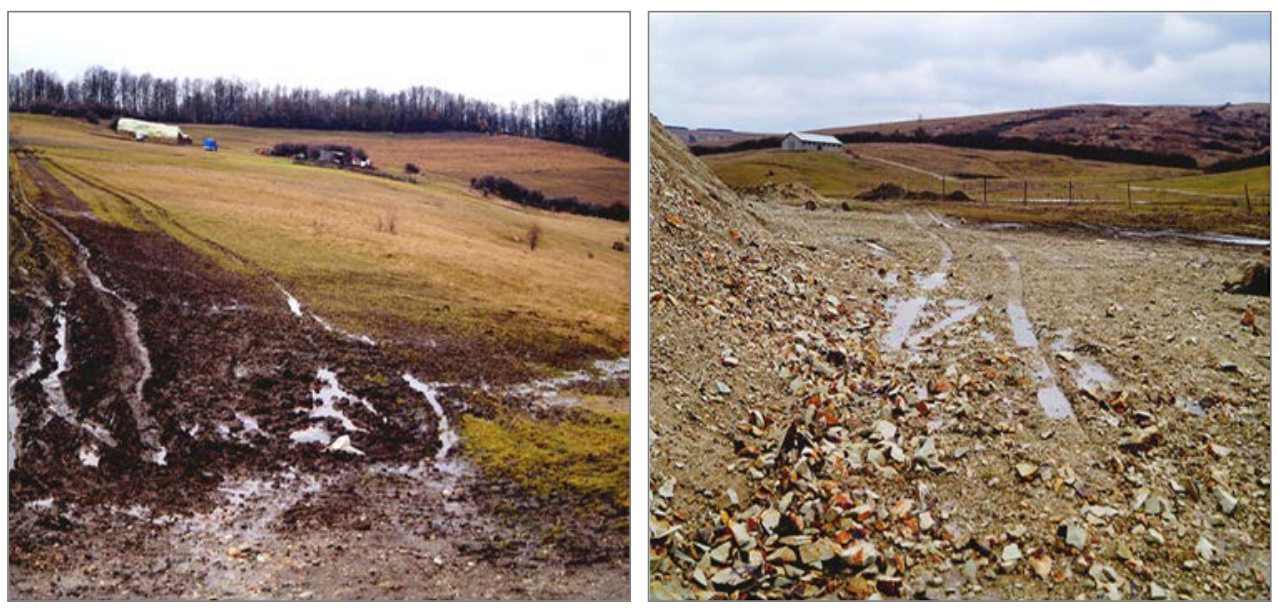

Fig.4. Ice wedges in colluvial deposits within Măgura Coşeiului (source: the author)

Obviously, in this case, it is no longer possible to speak about large-scale permafrost in the morphological structure of Silvania Mountains, but the marks of it and the modifications to which it was submitted were numerous. The periglacial forms identified in the Silvania Mountains are represented by: structured soils; ice tongues; forms produced by thermoclastism; nivation forms; block fields; cryo-nivation forms (gelifluxions and fluvial forms). The structured soils are the most specific periglacial forms, which, in Silvania Mountains, can take the form of some polygons and striated soils made of parallel strips. The pronounced thermal contractions in stratified rock complexes have resulted in the fracture of soil in the shape of circles, stone polygons, which may have a size from a few centimeters up to tens of meters.

The freeze-thaw processes in Silvania soils led to the formation of chaotic cryoturbation structures, developed especially on plastics with low permeability (clays) in the form of ice wedges (fig. 4). They are characteristic to regions with average annual temperatures under $6^{\circ} \mathrm{C}$, which produced a series of fractures in the Silvania soils. The size of these wedges is from a few centimeters up to $2 \mathrm{~m}$ and they develop on sandy and marly terrains with a high degree of humidity and numerous annual cycles of freeze and thaw. Ice wedges were identified within the plains and terraces of Crasna and Barcău, especially in the form of small fractures affecting sandy deposits, gravels, clays and marls specific especially for Șimleu Basin. 


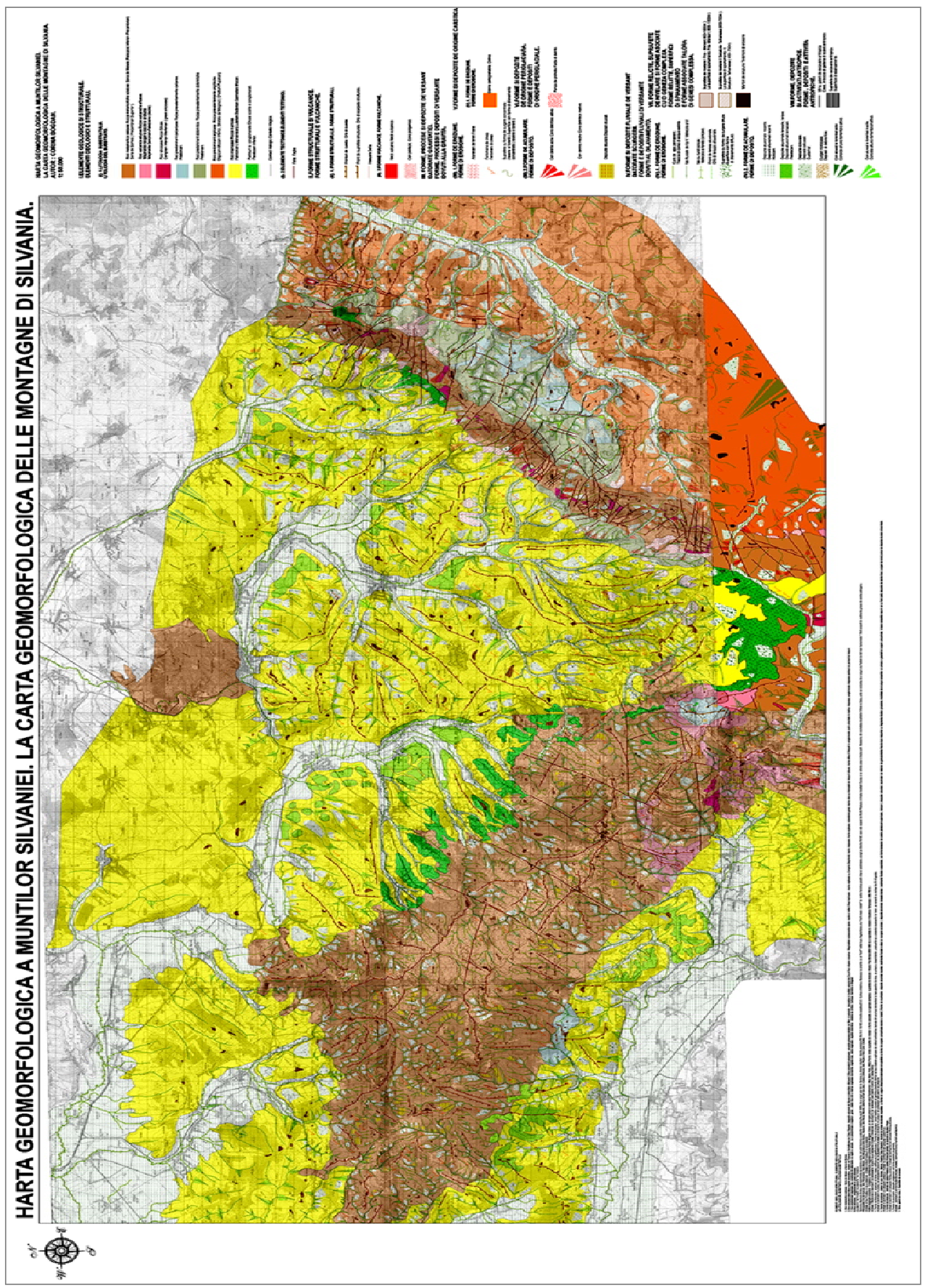




\begin{abstract}
HARTA GEOMORFOLOGICA A MUNTILOR SILVANIEI.
LA CARTA GEOMORFOLOGICA DELLE MONTAGNE DI SILVANIA.

AUTOR : CORINA BOGDAN.
\end{abstract}

I.ELEMENTE GEOLOGICE SI STRUCTURALE.

ELEMENTI GEOLOGICI E STRUTTURALI.

(1). 1.titologia substratului.
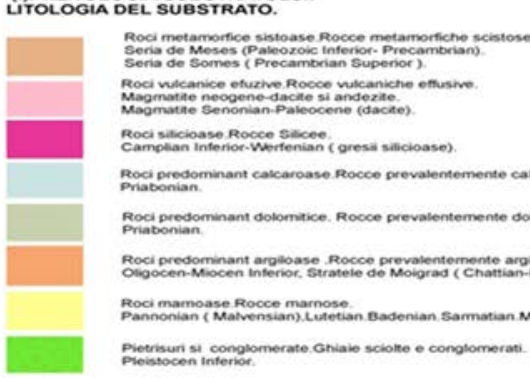

Roci predominant calcaroase Rocce prevalentemente cakaree
Prabonian.

Roci predominant dolomatice. Rocce prevalentemente dotomitiche

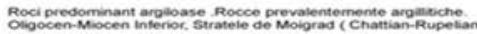

Raci mamoase Rocce marnose

Pietribur si conglomerate. Ghiaio scloilte e conolomerati.

Contact litologic Contatto libopico

III. FORME, PROCESE SI DEPOZITE DE VERSANT DATORATE GRAVITATIEI.

FORME, PROCESSI E DEPOSITI DI VERSANTE

DOVUTI ALLA GRAVITA.

(iii). 1.FORME DE EROZIUNE.

FORME DI EROSIONE.

Whinecande teren Frane.

Fenomene de creep. Fenomeni di creep.

Supratete cu forme de curgere concentrata
Gavene si torenti) Supperticio con forme di daavamento
concentrato ( ravene e torenti )

(iii).2.FORME DE ACUMULARE.

FORME DI DEPOSITO.

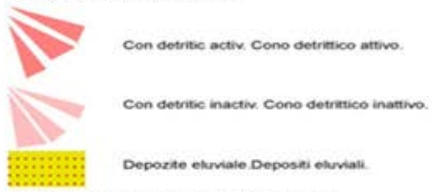

(IV).2. FORME DE ACUMULARE

FORME DI DEPOSITO.

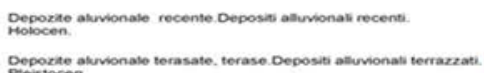

Deporine colkviale, Deposite collumat
Cuatemar.

Curgen morotioase. Deposes a debris now.

Con aluvial si torential activ Conobde allumo torrentizio attino.

Con aturnal st torential inactiv. Conoide aturio-iorrentivioinamino

VII. FORME RELICTE, SUPRAFETE DE NIVELARE SI FORME ASOCIATE CU O GENEZA COMPLEXA. FORME RELITTE, SUPERFICI DI SPIANAMENTO E FORME ASSOCIATE TALORA

DI GENESI COMPLESSA.

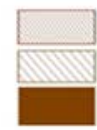

Supratata de nivelare I Pria - Merisor( $800-1000 \mathrm{~m}$ )
Ga superficie di spianamento Pria- Merisor ( $800-1000 \mathrm{~m}$ )

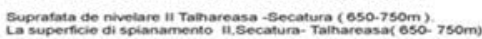

(1). 2.ELEMENTE TECTONICE.ELEMENTI TETTONICI.

II.FORME STRUCTURALE SI VULCANICE. FORME STRUTTURALI E VULCANICHE.

(ii). 1. FORME STRUCTURALE, FORME STRUTTURALI

- Fronturi de cuesta. Onlo di cuesta.

Fromt de supratata

(ii). 2.FORME VULCANICE, FORME VULCANICHE.

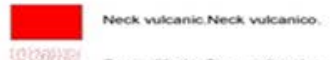

Drane, Dicoe

IV.FORME SI DEPOZITE FLUVIALE DE VERSANT DATORATE SCURGERII.

FORME E DEPOSITI FLUVIALI DI VERSANTE DOVUTI AL DILAVAMENTO.

(IV).1. FORME DE EROZIUNE.

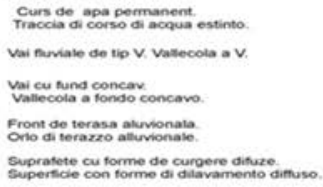

V.FORME SI DEPOZITE DE ORIGINE CARSTICA

(V).1. FORME DE EROZIUNE.

FORME DI EROSIONE.

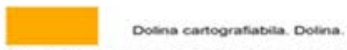

VI.FORME SI DEPOZITE DE ORIGINE PERIGLACIA FORME E DEPOSITI DI ORIGINE PERIGLACIALE.

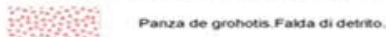

VIIIFORME, DEPOZITE SI ACTIVITATI ANTROPICE FORME, DEPOSITI E ATTIVITA ANTROPICHE.

- Mana, patern de excavare antropica

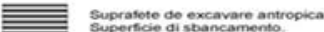

Marton de eroziune Testimoni di erosiono

Fig. 5. The geomorphological map of Silvania Mountains and its legend (source: the authors) 
The non-uniform response of these particles to freeze created tensions in these materialized deposits, especially through involutions.
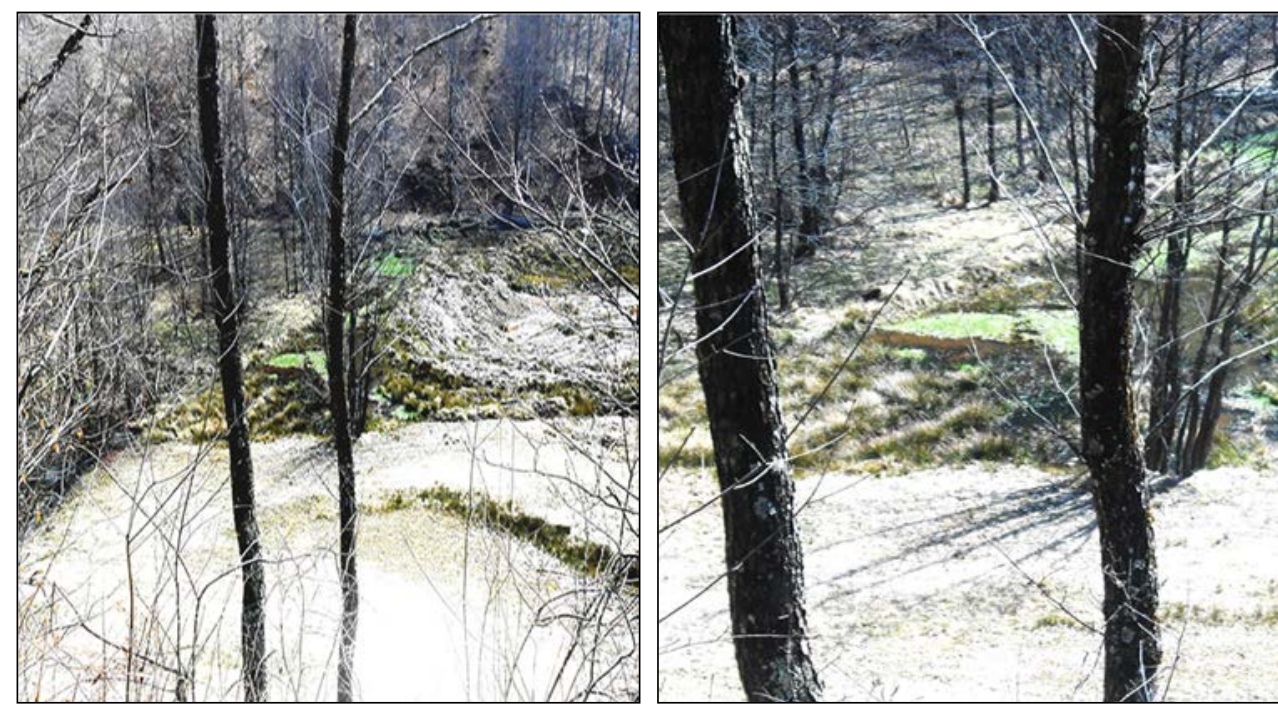

Fig. 6. Periglacial modeling in Plopiş Mountains, Ponor Karst Plateau (thaw lake) (source: the authors).

\subsection{Accumulation forms}

The periglacial forms of accumulation within the Silvania Mountains are highlighted by two categories of forms, those developed on the slopes and those due to gelifraction and gravitation.

3.2.1. Forms developed on the slopes, of solifluction and mud flow type, are noticed especially on the slopes in the mountainous area within Barcău, Crasna and Zalău catchment areas. The creeping has an important contribution to the development of these forms through fine movements of the particles on the slightly inclined slopes, covered by vegetation, independent from each other, in particular on the slopes in Plopiș Mountains, inside the covering deposits (Negreni Plateau, the slopes related to Valea Secătura, Șerani, Făgetu, Dealu Zboriște, Dealul Vuica, Valea Mare, Gepișul, Drighiul, Valea Cerăsei, Izvorul, Bistra and Pădurea Neagră Plateau) (fig. 5). In Meseș Mountains, the creeping phenomena cover a smaller area compared to Plopiș Mountains. They are present on Dealul Boului, west of Dosu Sigăului, Mezeșu, Peringaru, Dealu Cocina, Măgura Moigradului, Stâna, 
Ciumărna, Treznea. West of Dosu Sigăului, Obârșia Peak, Dealu Mânăstirii, Băile Meseșenii de Sus and Carpeni, one can notice mud flows as a result of periglacial modeling (see fig. 6). The creeping phenomena also affected the slopes of Măgura Şimleului (Dealul Sfântului, Muntele Rău, Dealul Varului, Cehei East, Dealul Uileac) and Măgura Coşeiului (La Păşune, Dealul Făgețel, Dealul Ţiganilor, Dealul Mihai Viteazul, Pădurea Ascuţită).

\subsubsection{Forms of detritus type due to gelifraction and gravitation,} resulting from the desegregation of rocks through freeze-thaw, which, due to rolling and collapse on the slopes, accumulate at their bottom in the shape of cones or flat pieces of ground, a common phenomenon at the contact of Meses hemi-anticline and Șimleu Basin. Within Meseș, in the western part of Măgura Priei, East of Măgura Stânii, West of Dosu Sigăului, Obârșia Peak and Dealul Mânăstirii, there are extended detritus nappes, especially in the immediate vicinity of Măgura Stânei. Forms due to thermoclastism processes or thermokarst landforms in Silvania Mountains are attributed to the degradation of permafrost, thus presenting a basin shape closely connected to the melting of its superficial part. This phenomenon is specific to predominantly limestone soils in Plopiş Mountains and Măgura Coşeiului. In Plopiş Mountains, in Ponor Plateau sector, we identified a thaw lake (fig. 6).

This lake was formed as a result of a pronounced subsidence induced by the thawing of permafrost. Admittedly, the formation of this lake was conditioned by climatic causes. In time, this lake will be covered with peat deposits and sandy and marly sediments. The forms of periglacial nivation in the Silvania Mountains developed against a background of intense shaping processes, such as processes of nivation or cryo-nivation due to the presence and permanence of the snow layer. The periglacial modeling depends on the weight of the snow and the slopes inclination in Silvania Mountains. Thus, at the level of valleys, it became manifest through the lowering of slopes and the reduction of heights. The most effective processes of nivation or gelivation take place in the upper convex sections of the slopes, characterized by a slow discharge compared to the lower sector, which presents a pronounced mobility due to denudation processes.

Thus, the morphodynamic evolution of these slopes is marked by a withdrawal tendency through cryoclastism, followed by successive accumulations as a result of the evacuation of materials from the upper sections. The sector morphodynamics of the Silvania slopes takes places in the two sections of erosion and accumulation, with a continuous tendency of advancement against the eroded terrain, in this way reaching a slope of dynamic balance of the glacis type. Their development in Silvania Mountains, especially on the eastern slopes of Plopiș Mountains, Măgura Coșeiului, the eastern part of Meseș Mountains, is the 
mark of the intense periglacial changes to which the territory was submitted, confirmed by the frosty and long winters and the documents of that period when the "Little Ice Age" LIA was mentioned. The flow phenomena produced on the slopes by the partial or total melting of snow, rich in carbon dioxide, acted upon the carbonaceous rocks and created forms like channels, gliding deposits, avalanche corridors or stratified detritus nappes (fig. 7).
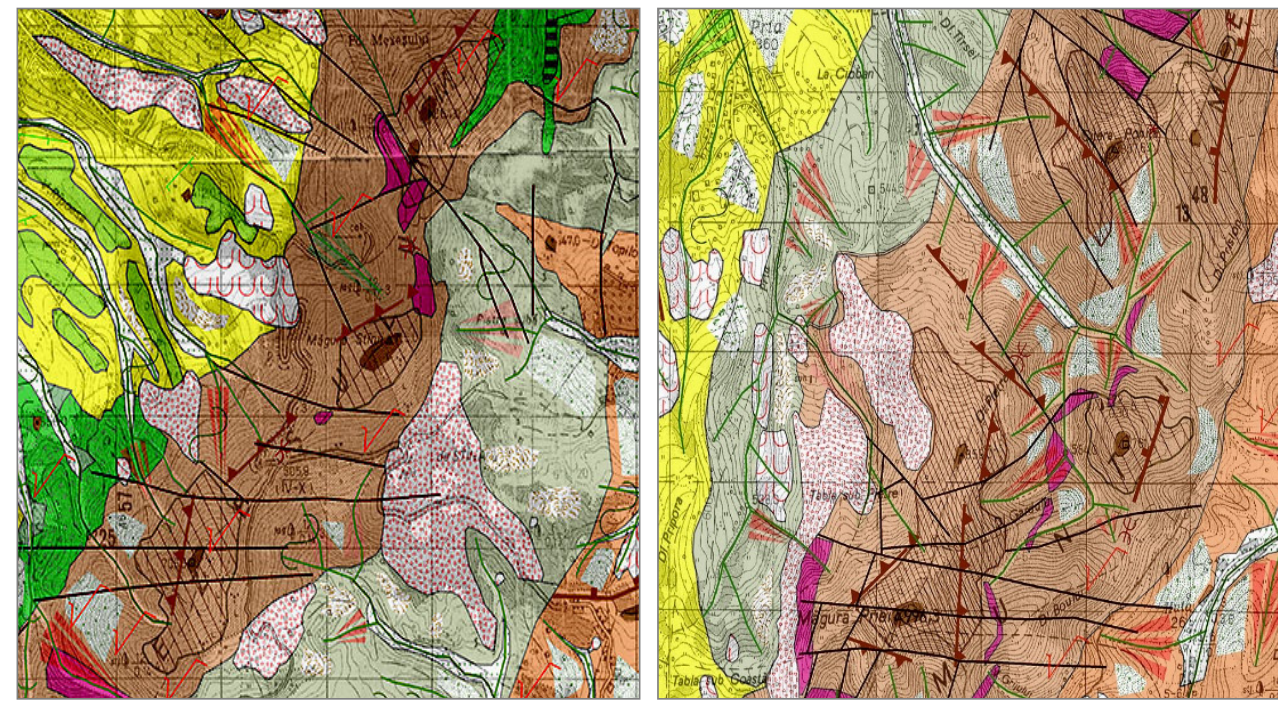

Fig. 7. Periglacial forms in Meseş Mountains (see legend of fig. 5, source: the author)

The avalanche corridors, relatively reduced in size in Silvania Mountains, have the form of strips without forest vegetation, consisting of detritic materials. The repeated cycles of freeze-thaw in the upper sections of the slopes led to the formation of nivation edges, due to the evacuations caused by intense desagregations, resulting in the formation of concavities in the slopes profile. The clastic rocks resulting from these processes were moved by the lower sectors of the slopes as a result of diffuse flow processes. Therefore, due to the periglacial modeling, residual landforms were created (sharp summits, towers, pins, wedges, involutions) and forms of accumulation (of the nappes and detritus cones type). The presence of gelisol can be deduced from the variety and extension of cryoturbation forms (involutions, wedges and congelifluctions), found mostly in terrace deposits and delluvial - colluvial deposits. The lithological and structural variety is important for the development of periglacial processes in Silvania. 
In the Șimleu Basin and Măgura Coşeiului, compared to Plopiş and Meseş Mountains and Măgura Şimleului, there are asymmetric valleys, cuestas and a front glacis on the monoclinal structures and solid rocks (limestones, sandstones and tuffs), on whose lower parts loessoid or grèzes litées formations were deposited. On clays and marls instead, slopes of solifluctional balance were formed and landslides took place, triggered by the frequency and intensity of floods (on Agrij Valley) during the thawing periods, which led to the creation of the wide valleys due to gelifluviation. During the period of heating, through thawing, the rivers involved in the flow processes large quantities of materials from the banks degraded by gelifraction, due to lateral erosion, in the presence of this gelisol (Crasna and Barcău Valleys). In conclusion, the periglacial landscape in Silvania Mountains is well represented both as regards the forms of accumulation and erosion, through structured soils; ice tongues; forms produced by thermoclastism; nivation forms; block fields; cryo-nivation forms (gelifluctions and fluvial forms).
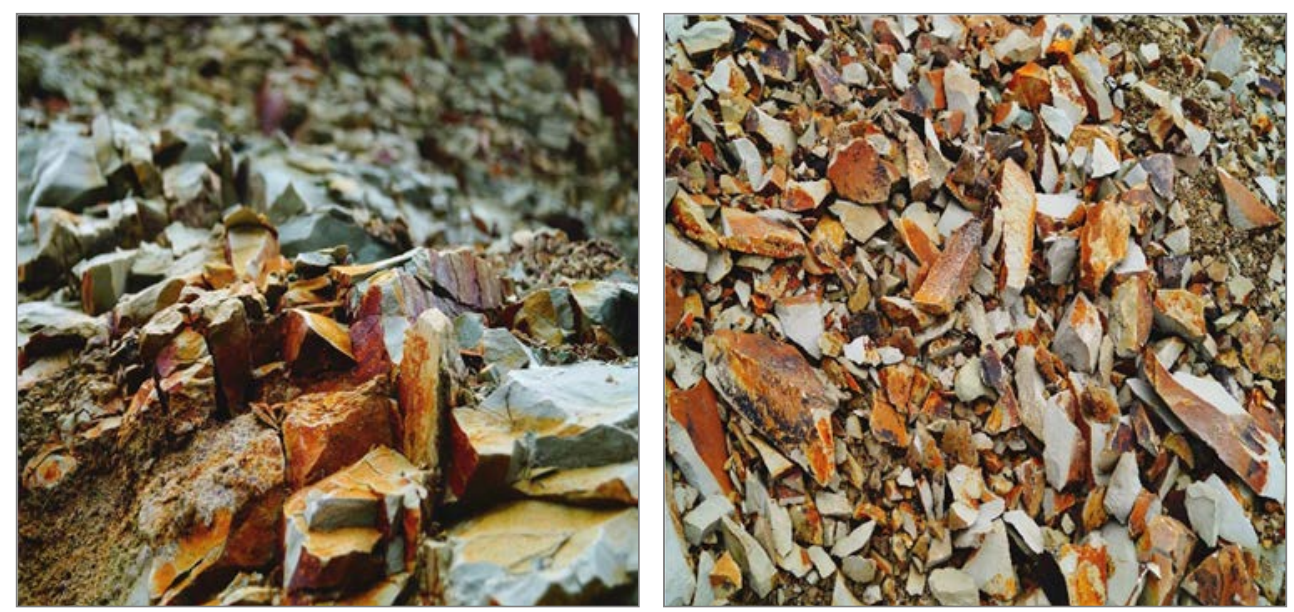

Fig. 8. Detritus nappes in Măgura Coșeiului (source: the author)

The most prominent marks of the periglacial modeling are found in Meseş Mountains compared to other units of Silvania Mountains due to the presence of forms of erosion and accumulation, such as those developed on the slopes (solifluctions and mud flows) as well as those resulting from gelifraction (detritus nappes) (fig. 8). Meseş Mountains are different from the other units through the wide presence of the periglacial detritic layer, represented by the stratified detritic nappes on both sides. 


\section{THE DISTRIBUTION OF TERRAINS IN SILVANIA MOUNTAINS ACCORDING TO THEIR USE}

The Silvania soils are a product of synthesis, the result of the integration between abiotic and biotic matter, but they also store nutrients, energy and water for plants, providing their vital elements, as the environment in which they develop.
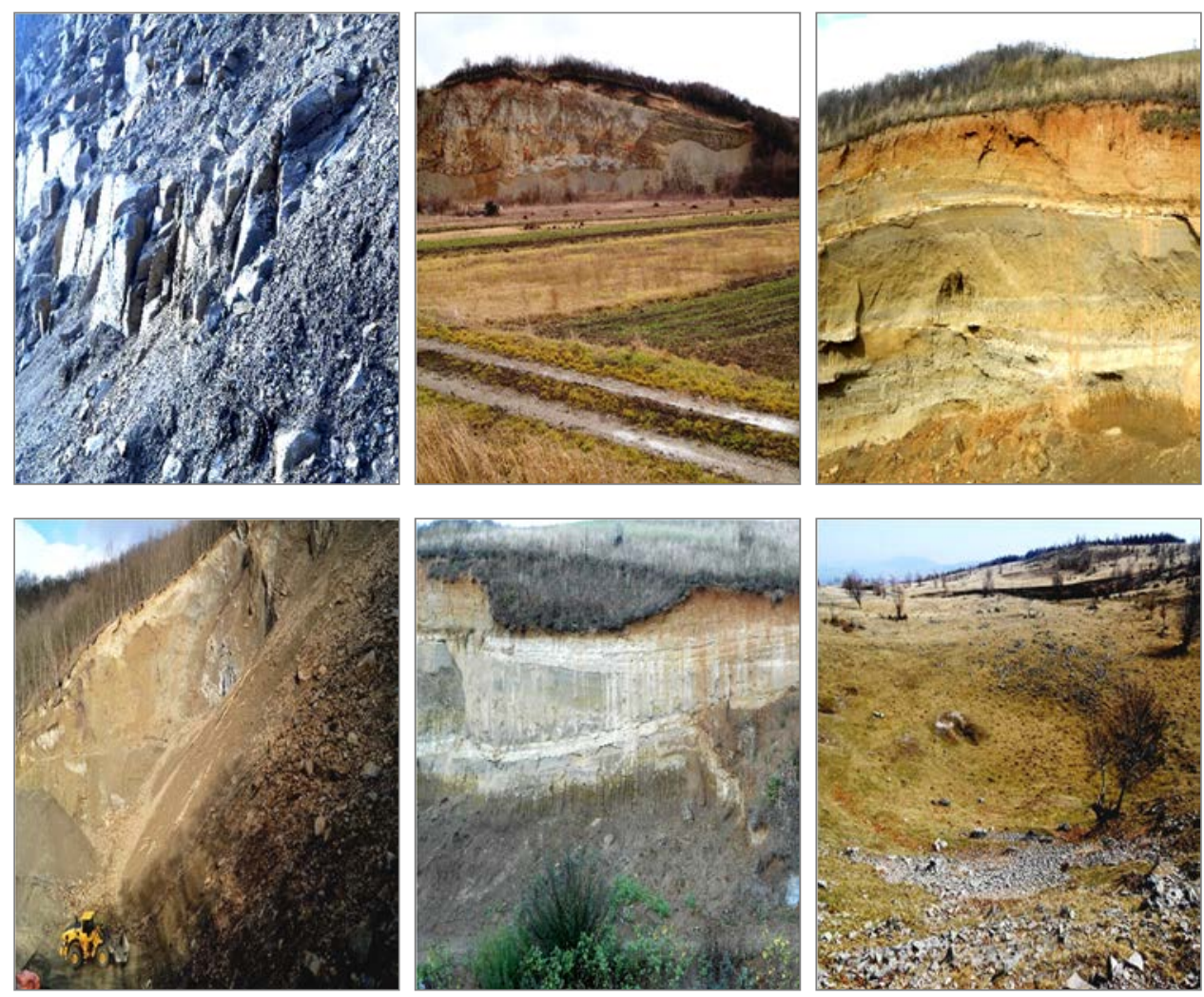

Fig. 9. Regosols in Meseş Mountains, pseudorendzines in Măgura Coşeiului, Măgura Şimleului, cambisols in Plopiş Mountains

(source: the author)

Silvania soils were formed at the contact between the lithosphere, biosphere and atmosphere due to physical, chemical and biological interactions. In Silvania Mountains, one notices the domain of cambisols and argiluvisols, specific to low mountains. According to the physical and geographical conditions and their role in 
the distribution of main soil types, a more detailed analysis reveals a weak vertical zonality. The uniform soil formation processes in Sălaj County led to the emergence of forest soils, in such classes like brown forest soils, podzols and argiluvisols, while brown acid soils are in Măgura Şimleului and Coșeiului.

Brown soils and brown forest soils are characterized by different stages of podzolization from low to average, and represent the most widespread class in Silvania Mountains. Tertiary sedimentary deposits in Şimleu Basin and Almaș-Agrij Basin conditioned the formation of podzols and argiluvisols, varied as texture and supported by delluvial and proluvial deposits (sands, sandstones, clays and marls). In the floodplains and terraces of the rivers Barcău, Crasna, Zalău, Agrij and Almaş there are intrazonal soils, from the category of mineral hydromorphic and lithomorphic soils formed during a sinuous process of integration between landscape, rock and phreatic waters. Lithomorphic soils are represented by rendzines and pseudorendzines (fig. 9), which cover limited areas, being specific to the south-eastern slopes of Meses Mountains and to the upper basin of Almaș, in the area of limstones and argillaceous deposits with high levels of calcium carbonate due to scarps.

Table 1. Land distribution according to quality classes (source: Sălaj Office of Pedological and Agrochemical Studies)

\begin{tabular}{|c|c|c|c|c|c|c|c|c|c|c|}
\hline \multirow{2}{*}{} & \multicolumn{2}{|c|}{ Class I } & \multicolumn{2}{c|}{ Class II } & \multicolumn{2}{c|}{ Class III } & \multicolumn{2}{c|}{ Class IV } & \multicolumn{2}{c|}{ Class V } \\
\cline { 2 - 12 } & ha & $\begin{array}{c}\text { \% } \\
\text { from } \\
\text { the } \\
\text { total } \\
\text { use }\end{array}$ & ha & $\begin{array}{c}\text { \% } \\
\text { from } \\
\text { the } \\
\text { total } \\
\text { use }\end{array}$ & ha & $\begin{array}{c}\text { \% } \\
\text { from } \\
\text { the } \\
\text { total } \\
\text { use }\end{array}$ & ha & $\begin{array}{c}\text { \% } \\
\text { from } \\
\text { the } \\
\text { total } \\
\text { use }\end{array}$ & ha & $\begin{array}{c}\text { fom } \\
\text { frome } \\
\text { the } \\
\text { total } \\
\text { use }\end{array}$ \\
\hline Arable & 53 & 0.04 & 5,247 & 4.35 & 35,838 & 29.72 & 48,751 & 40.43 & 30,699 & 25.46 \\
\hline Grasslands & 1,517 & 2.03 & 5,642 & 7.56 & 12,350 & 16.54 & 23,644 & 31.66 & 31,519 & 42.21 \\
\hline Meadows & 992 & 2.70 & 2,882 & 7.84 & 5,271 & 14.33 & 13,135 & 35.71 & 14,501 & 39.43 \\
\hline Vineyards & - & - & 52 & 2.08 & 315 & 12.60 & 1,258 & 50.32 & 875 & 35.00 \\
\hline Orchards & 10 & 0.23 & 233 & 5.27 & 494 & 11.16 & 2,384 & 53.88 & 1,304 & 29.47 \\
\hline
\end{tabular}

The hydromorphic soils are specific to areas with humidity levels in excess in Șimleu and Almaș-Agrij basins, where the reduced discharge slope and the presence of impermeable deposits favored the formation of meadow black soils, humic-gleic soils and wetlands, soils predominantly used for pastures and meadows. The floodplain soils are represented by alluvial deposits and especially by alluvial soils with different degrees of humification, which have the shape of strips along the Someș, Almaș, Agrij, Crasna, Zalău and Barcău valleys. 

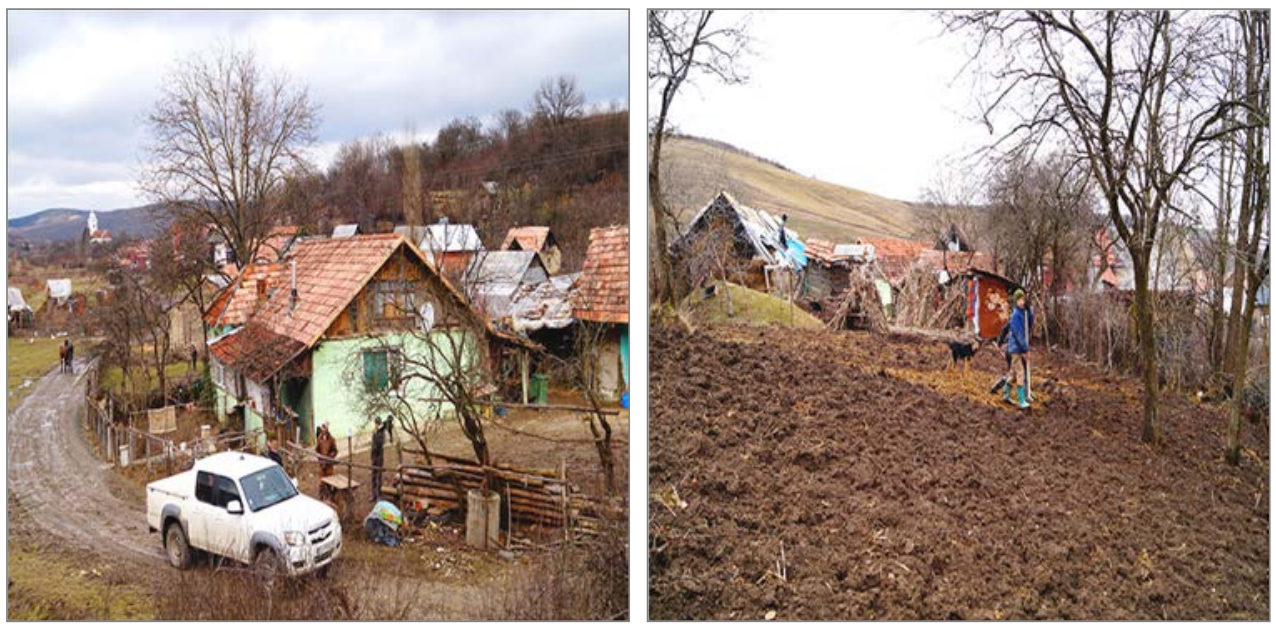

Fig. 10. Subsistence farming in Măgura Coșeiului, Coșeiu (source: the author)

The distribution of land according to the category of use in Sălaj County and in the Silvania Mountains is presented as follows: agricultural land (arable lands, grasslands, meadows, vineyards and orchards), forests and forested lands, land with water and reed, communication ways and railways, lands with buildings and yards, degraded and unproductive lands and non-agricultural land. The statistics carried out at the level of Sălaj County indicate that most of the areas in Silvania Mountains have an agricultural character. According to data provided by the Sălaj Office of Pedological and Agrochemical Studies, the major share belongs to arable areas with pastures and orchards in Silvania Mountains and the surrounding areas.

The agricultural lands in Silvania Mountains have natural qualities which constitute the fundamental premise for agricultural activities. The soil quality influences the water and air quality and the nutrients cycle. The soils in Sălaj County have a low fertility due to practice of subsistence farming (fig. 10), requiring high expenses for crops and therefore sometimes the owners of agricultural lands abandon them. According to data provided by the Sălaj Direction for Agriculture and Rural Development, the total agricultural land covers 238,966 ha. In the table below, one notices the fact that the area of agricultural lands at the level of Sălaj County has gradually reduced from 1999 to 2010, while it increased during 2011. As regards the agricultural use of soil on categories of use, during 2011 we can notice an increase in the arable lands, meadows, pastures, orchards, and a decrease in the lands covered by vineyards. 

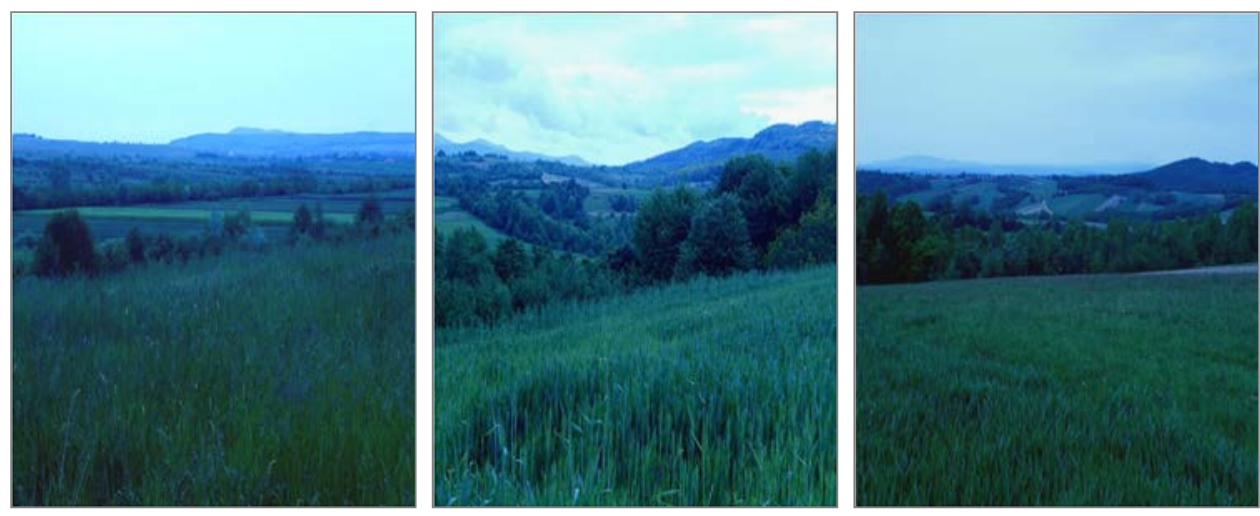

Fig. 11. Arable land with corn and barley crops in Silvania Mountains (Plopiș and Meseș Mountains) (source: the author)

Concerning the areas removed from the agricultural circuit, the table below shows their significant variation in particular for arable lands and pastures between 1999 and 2012. Compared to 2011, 4 ha of land were included again in the agricultural circuit during 2012.

Table 2. The distribution of land according to their use (source: Sălaj Direction for Agriculture and Rural Development)

\begin{tabular}{|c|c|c|c|c|c|c|c|}
\hline \multirow{2}{*}{$\begin{array}{c}\text { Current } \\
\text { row }\end{array}$} & \multirow{2}{*}{ Year } & \multicolumn{5}{|c|}{ Category of use } & \multirow{2}{*}{$\begin{array}{c}\text { Total } \\
\text { agricultural } \\
\text { lands }\end{array}$} \\
\hline & & Arable & Grasslands & Meadows & Vineyards & Orchards & \\
\hline 1. & 1999 & 123,715 & 78,090 & 32,082 & 2,627 & 4,969 & 240,943 \\
\hline 2. & 2000 & 123,401 & 77,896 & 31,974 & 2,620 & 5,052 & 240,943 \\
\hline 3. & 2001 & 123,557 & 77,902 & 31,923 & 2,580 & 4,826 & 240,788 \\
\hline 4. & 2002 & 122,603 & 78,314 & 32,566 & 2,578 & 4,720 & 240,781 \\
\hline 5. & 2003 & 121,534 & 78,738 & 33,861 & 2,413 & 4,156 & 240,702 \\
\hline 6. & 2004 & 121,505 & 78,814 & 34,320 & 1,936 & 4,115 & 240,690 \\
\hline 7. & 2005 & 121,495 & 78,577 & 33,924 & 2,568 & 4,097 & 240,661 \\
\hline 8. & 2006 & 121,554 & 78,504 & 33,894 & 2,621 & 4,088 & 240,661 \\
\hline 9. & 2007 & 121,430 & 78,508 & 33,952 & 2,586 & 4,085 & 240,561 \\
\hline 10. & 2008 & 120,570 & 78,507 & 34,807 & 2,586 & 4,085 & 240,555 \\
\hline 11. & 2009 & 120,447 & 76,039 & 36,014 & 2,564 & 4,330 & 239,394 \\
\hline 12. & 2010 & 120,572 & 74,348 & 36,609 & 2,564 & 4,323 & 238,416 \\
\hline 13. & 2011 & 120,588 & 74,672 & 36,781 & 2,500 & 4,425 & 238,966 \\
\hline 14. & 2012 & 120,586 & 74,671 & 36,780 & 2,500 & 4,425 & 238,962 \\
\hline
\end{tabular}


The main geomorphological processes affecting the soil quality are represented by water and wind erosion (which causes the loss of fertile soil layer on the surface, the land deformation, clogging and sedimentation); compaction; landslides; excess water; the low amount of organic matter and nutrients in the soil; salinization; acidification; pollution. The linear and areolar erosion is by far the most important factor in land degradation.

Table 3. The areas removed from the agricultural circuit in Silvania Mountains (source: Sălaj Direction for Agriculture and Rural Development)

\begin{tabular}{|c|c|c|c|c|c|c|c|}
\hline \multirow{2}{*}{$\begin{array}{c}\text { Current } \\
\text { no. }\end{array}$} & \multirow{2}{*}{ Year } & \multicolumn{5}{|c|}{ Category of use (ha) } & \multirow{2}{*}{$\begin{array}{c}\text { Total } \\
\text { agricultural } \\
\text { lands (ha) }\end{array}$} \\
\hline & & Arable & Grasslands & Meadows & Vineyards & Orchards & \\
\hline 1. & 1999 & 0.35 & 1.32 & 0.55 & 0 & 0 & 2.22 \\
\hline 2. & 2000 & 2.74 & 0 & 0.01 & 0 & 0 & 2.75 \\
\hline 3. & 2001 & 0.57 & 3.90 & 0.06 & 0 & 0 & 4.53 \\
\hline 4. & 2002 & 4.49 & 22.0 & 0.01 & 0 & 0 & 26.50 \\
\hline 5. & 2003 & 0.70 & 0 & 0 & 0 & 0 & 0.70 \\
\hline 6. & 2004 & 10.58 & 0.40 & 0 & 0 & 0 & 10.98 \\
\hline 7. & 2005 & 1.33 & 1.21 & 0 & 0 & 0.03 & 2.57 \\
\hline 8. & 2006 & 5.17 & 0.14 & 0.11 & 0.06 & 0.25 & 5.73 \\
\hline 9. & 2007 & 27.14 & 14.00 & 0.55 & 0.08 & 1.25 & 43.02 \\
\hline 10. & 2008 & 5.15 & 1.00 & 0.18 & 0.01 & 0.04 & 6.38 \\
\hline 11. & 2009 & 6.29 & 0.26 & 1.9 & 0 & 0.06 & 8.51 \\
\hline 12. & 2010 & 6.73 & 2.85 & 1.37 & 0.10 & 0.14 & 11.10 \\
\hline 13. & 2011 & 2.03 & 0.08 & 0.38 & 0.03 & 0.25 & 2.77 \\
\hline 14. & 2012 & 2.35 & 1.24 & 0.21 & 0.03 & 0.08 & 3.91 \\
\hline
\end{tabular}

Among the various forms of erosion, the most widespread is the surface discharge, having consequences so severe that the land can no longer be used from an agricultural point of view, so it must be removed from the agricultural circuit. At the level of Sălaj County, according to data provided by the National Administration of Land Improvements - Someș-Tisa Branch, the following phenomena were reported concerning the agricultural surface: strong surface erosion $(10,375 \mathrm{ha})$, in depth erosion (4657 ha), the modification of the geochemical composition (159 ha), landslides (8,343 ha), geological erosion (356 ha), bank erosion (109 ha), excessive humidity (8 $961 \mathrm{ha})$, valueless vegetation $(2,342)$, totaling an area of 35,700 ha. 


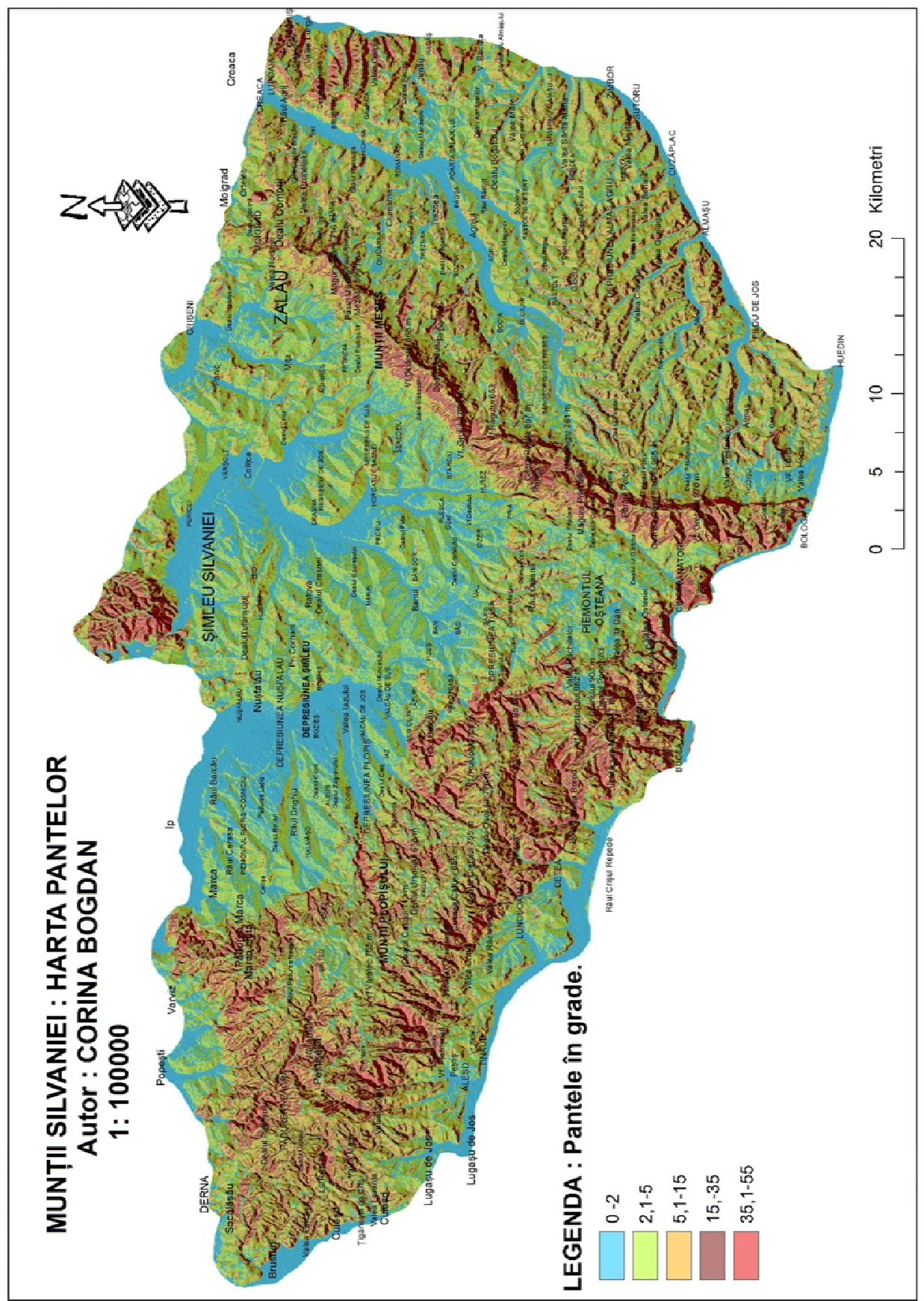

Fig. 12. The Silvania Mountains, the map of slopes (source: the author) 
The agricultural technological faults are the most important causes of the chemical degradation, to which we add the industrial and bio-industrial activities. These phenomena appeared as a result of non-compliance with the rules for the implementation of agricultural works, depending on land requirements, storage of residues from zootechnical activities and fishing accumulations. As previously mentioned, of the total area of Sălaj County (386,438 ha), 240,690 ha (62.28\%) represent agricultural land, while the rest of 145,748 ha (37.72\%) consists of non-agricultural lands (forests, land, lands with water, railways, communications ways, land with building etc). Most of the agricultural land is represented by arable land (50.42\%), followed by the grassland (32.83\%), meadows (13.91\%), vineyards and orchards. As regards the areas affected by various degradation factors, the most important is the phenomenon of surface erosion (68.6\%), followed by smaller percentages of excessive humidity $(11.1 \%)$, landslides $(10.3 \%)$ and other factors.

Most of the agricultural lands (62\%) have the slope between 6-14 ${ }^{\circ}$ (see fig. 12), being cultivated with vineyards and orchards. $15 \%$ of lands have the slope under $6^{\circ}$ and they are specific to cereal crops. It turns out that approximately on one-quarter $(23 \%)$ of the agricultural area, the mechanized works can be done with great difficulty due to the degree of inclination of the terrain (slope $>14^{\circ}$ ). According to the above-mentioned aspects and in agreement with the Environmental Protection Agency Sălaj, the soils of Silvania are essential for meeting the primary needs of human communities, thus, at least until the invention of artificial photosynthesis, we all depend on the thin and fertile layer from the Earth's surface, from where we extract all the necessary resources.

\section{THE EFFECTS OF CRIONIVAL PROCESSES ON THE TYPES OF AGRICULTURAL USE OF LAND IN SILVANIA MOUNTAINS}

Due to their position, Silvania Mountains are situated in the temperate continental climate area, representative for the western and northwestern areas of Romania, under the influence of some prevailing western and northwestern winds. Consequently, during winter, as a result of the polar circulation, which moves polar or arctic air masses, winter is quite frosty and humid, and during spring and autumn, the frequency of freeze rises to $30 \%$ and affects the northern part of the Silvania area.

The effects of the southern or southwestern circulation are felt through higher temperatures and rainfall in proportion of over 15\%, as a result of warm air from the South-West, characteristic to northern Mediterranean cyclone activity, in 
its movement towards North. The climate represents an essential factor, through the influences induced in the dynamics of the geomorphological processes, by means of its two elements, rainfall and air temperature, that have an important impact on some natural processes (meteorization, erosion, the formation of flow from riverbeds, soil formation). The influence of climate is equally felt in the characteristics of flora and fauna. It can favour or restrict the anthropogenic activity. Particularly, it fosters the agricultural activity, through favourable periods for certain cereal and technical crops, fruit-growing, vegetable growing, farming (Josan, 2009). The climate conditions equally influence other forms of the anthropogenic activity (the transport and building industry) and have implications in man's health and environment. To this effect, one should mention the Little Ice Age (comprised between the $16^{\text {th }}$ and $18^{\text {th }}$ century), a period of important cooling. Currently, the increase in the average temperature $\left(0.6^{\circ} \mathrm{C}\right.$ in the last 50 years) was rather associated and assigned to the excessive anthropogenic pressure (the greenhouse gases are suggestive to this effect) and not as much to natural factors such as the orbital forcing, the solar variations and volcanic eruptions (Bindoff et al., 2013).

As regards the climatic factors, which impose the features of the climate in a certain geographical area, the solar radiation is the determinant climatic factor - the lowest values of solar radiation were recorded during the cold season $\left(10.75 \mathrm{kcal} / \mathrm{cm}^{2} /\right.$ year at Nușfalău).

$A$. The duration of sunlight brightness records the highest values during summer, in July and August - 282 hours/month, in Zalău, and the lowest, during winter, 70 hours/month, at the same weather station. In the context of the current running-out of non-renewable energy resources, the length of daylight is of interest, in the purpose of its exploitation as an inexhaustible source of energy, in view of the fact that during four months out of twelve (May-August), the duration of sunlight brightness is, on average, about 9 hours/day.

$B$. The conditions of temperature: the temperature is not a constant quantity, it varies according to the season, altitude, cloudiness. In Silvania area, the multi-annual average temperature records values that drop considerably from West towards East (Zalău, $10.6^{\circ} \mathrm{C}$; Nușfalău, $9.5^{\circ} \mathrm{C}$ ). This would be explained by the altimetric position of the weather stations and by their closeness to the mountain area. Consequently, we can state that, for the most part of the Silvania area, the multiannual average temperature is of $10^{\circ} \mathrm{C}$. Between 2011 and 2015 an increase in the annual average temperature was recorded in the Silvania Mountains from $10.5^{\circ} \mathrm{C}$ to $11.7^{\circ} \mathrm{C}$ with several implications in the dynamics of the Silvanian ecosystems. Related to temperature, we must mention freeze, which can cause serious damage to agriculture. In Silvania, the first freeze is recorded in midOctober and the last freeze in mid-April. The growing frequence of extreme 
weather events during the last two decades was instrumentally proved. The climate simulations denote the tendency towards warming and the more and more relevant impact of the anthropogenic factor in comparison with the natural variability.

Table 4. Annual average temperature, rainfall and winds in the Silvania Mountains, between 2011and 2015

(source: The National Meteorological Administration, Cluj Branch)

\begin{tabular}{|c|c|c|c|}
\hline Year & $\begin{array}{c}\text { Annual average } \\
\text { temperature }\left({ }^{\circ} \mathbf{C}\right)\end{array}$ & $\begin{array}{c}\text { Monthly rainfall } \\
\left(\mathbf{l}^{\mathbf{m}} \mathbf{m}^{\mathbf{2}} \mathbf{)}\right.\end{array}$ & $\begin{array}{c}\text { Wind - main } \\
\text { direction } \mathbf{( m} / \mathbf{s})\end{array}$ \\
\hline $\mathbf{2 0 1 1}$ & 10.5 & 389.6 & $\mathrm{NW} / 2.1$ \\
\hline $\mathbf{2 0 1 2}$ & 11.2 & 568.7 & $\mathrm{NW} / 2.2$ \\
\hline $\mathbf{2 0 1 3}$ & 11.2 & 693.4 & $\mathrm{NW} / 2.3$ \\
\hline $\mathbf{2 0 1 4}$ & 12.4 & 649.3 & $\mathrm{SE} / 2.1$ \\
\hline $\mathbf{2 0 1 5}$ & 11.7 & 626.1 & $\mathrm{SE} .1 .9$ \\
\hline
\end{tabular}

It is a well-known fact that $90 \%$ of the natural disasters are related to weather, climate and waters. Thus, the global and regional climate changes contribute to the increase of the frequency of meteorological risk phenomena such as droughts, rainfall, floods and freeze. In order to prevent these meteorological risk phenomena (dangerous meteorological phenomena - storms, floods, drought, frost) they have to be well studied and forecasted so as to reduce damages for the national economy and to guarantee people's security.

C. Rainfall: as concerns the spatial distribution of rainfall, in Silvania area one notices an increase in rainfall from West towards the mountains (Nușfalău, $621 \mathrm{~mm}$; Zalău $639.4 \mathrm{~mm}$ ), this being also fostered by the uniform morphology. Măgura Șimleului does not represent an obstacle in the way of the rainfall dissemination, so that, in average, the Silvania area records about 600 $\mathrm{mm}$ of precipitation from rain and snow. Higher average annual rainfall amounts (800 - $900 \mathrm{~mm}$ and even over $900 \mathrm{~mm}$ ) were recorded in the Meseș and Plopiș Mountains, as a result of the higher altitudes in comparison with the bordering regions and their aspect towards the western circulation. Between 2011 and 2015 the annual rainfall amount recorded fluctuations with an upward trend from $389.6 \mathrm{l} / \mathrm{m}^{2}$ to $626.1 \mathrm{l} / \mathrm{m}^{2}$. The rainfall amount does matter, because if it exceeds the average values, it can produce a series of dangerous natural (hydrological, geomorphological, pedological) phenomena with serious consequences for the human communities and therefore implicitly for the anthropogenic activity (floods, landslides, hails and storms). 

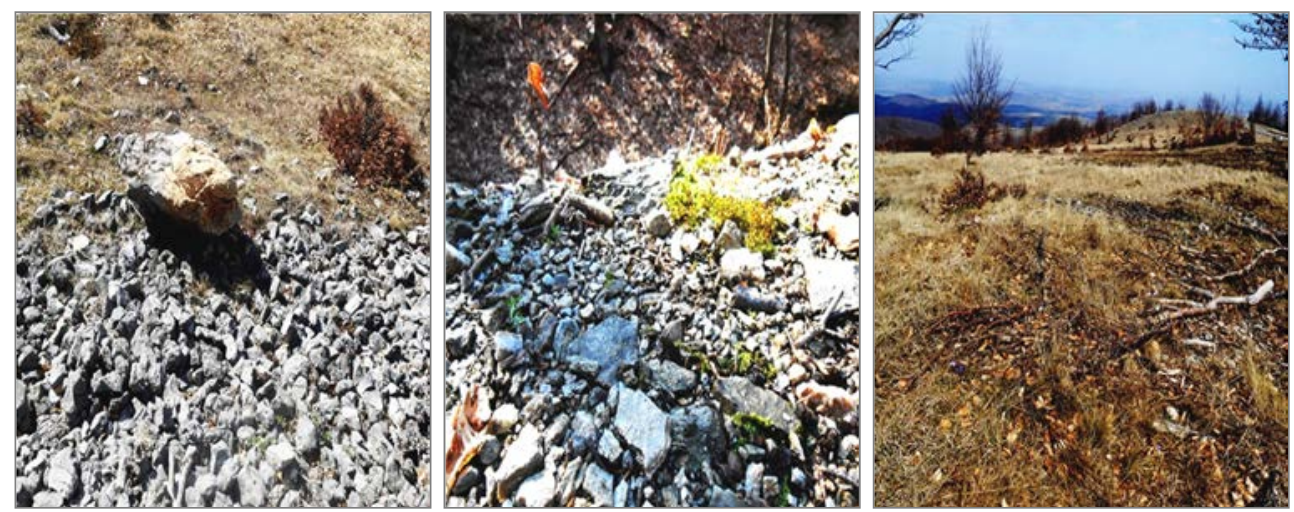

Fig. 13. Detritus and vegetable waste characteristic to some spring slides in Plopiș and Meseș Mountains (source: the author)

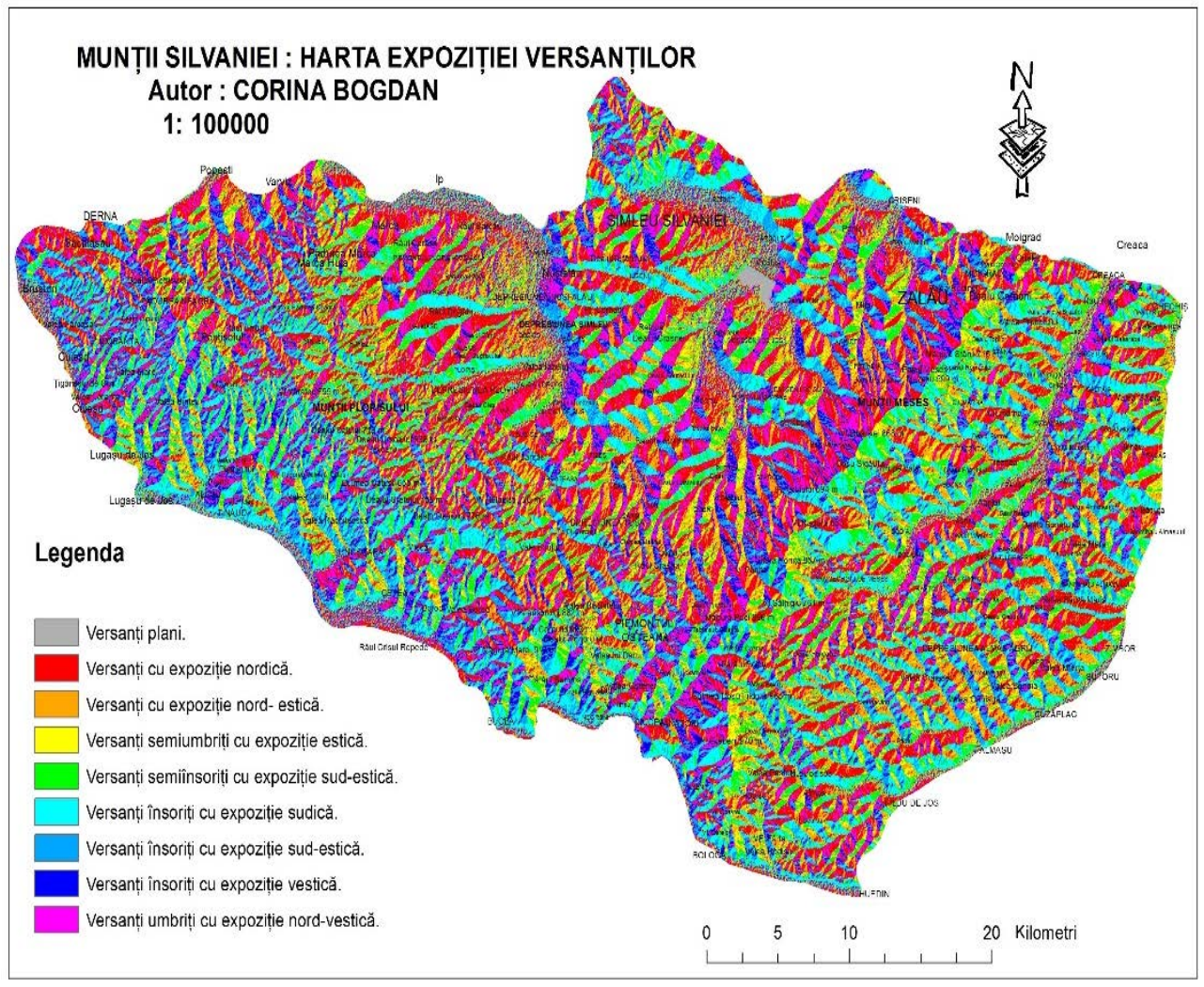

Fig. 14. The aspect of the slopes in Silvania Mountains (source map: the author) 
The snow layer is deposited and maintained in the days in which the soil and air temperature is negative. It is a good insulator and protects the autumn crops during the winter, reaching a thickness of around $16-17 \mathrm{~cm}$. (Josan, 2009). The snow layer can cause mechanical and chemical erosion processes, which depend on its persistence and thickness (Castiglioni, 1979). In the Silvania Mountains, the snow, through its mass, can compress the soil and vegetation if it moves, it uproots plants, agricultural crops, especially the fruit trees and the vineyards, and it moves detritus masses and facilitates various landslide phenomena of the avalanche type (see fig. 13). In its surroundings and under it, the snow causes particular thermic and humidity conditions, in a way that enhances or slows down the cryoclastic processes. Through melting, the snow layer supplies the flow of snow. Thus, the water resulting from the melting of snow is rich in carbon dioxide and has a very effective chemical action, as we can observe in the sinkholes on Negreni Tableland, in the South of Plopis Mountains. One of the most violent and spectacular phenomena in periglacial environments are the avalanches, snow, debritus and vegetable waste falls characteristic to the scarped slopes of Meses Mountains. These represent a considerable environmental risk factor. The most representative case is that of a small snow and air mass, which falls off from the snow-capped slopes and slides, growing as it takes in more snow and roots out vegetation, trees and debris, creating a gap in the slope's profile under the form of the "avalanche corridor", scratches the rock walls of the slopes and finally settles to the mountain base as fan-like amassments. Of course, in Silvania Mountains, there are only small size avalanches, but particularly dangerous for the orchards and vineyards through their uprootal.

They rarely occur especially in Meseș Mountains during spring when thaw processes take place, that move the ice or during winter when the snow layer is increased by snowfall. Avalanches may be due to accidental phenomena such as the fall of some masses of rocks or of a block of snow as a result of the passage of animals or skiers. This phenomenon threatens houses, communication ways, forests and agricultural crops in Silvania Mountains. These avalanches are specific to slopes $>20^{\circ}$ and northern aspect (which favors winter avalanches) and southern aspect (spring avalanches) according to the map regarding the aspect of slopes (see fig. 14). We distinguish the following typologies of avalanches in Silvania Mountains: incohesive snow avalanches (due to the slip of a small portion of fresh snow, which moves a major amount of snow, during the descent, it has the shape of tongues specific to Meseș Mountains); superficial avalanches depending on the thickness of snow, only certain superior layers of snow move, specific to Plopis Mountains; wet and dry snow avalanches according to the degree of snow humidity; corridor avalanches on the river valleys of the Silvania area, depending on the morphology of the slope. 
D: Air humidity depends on the origin of air masses, which arrive in Silvania Mountains, the rainfall frequency and the underlying surface. The largest amount of water vapors is found in the maritime and Atlantic air masses (western and north-western circulation) and in the Mediterranean maritime air (southern and south-western circulation) according to Cristea (2004). The multiannual average values of the relative humidity are of 81.7 in Nușfalău and 70.9 in Zalău, values which indicate the optimal humidity content for the development of biophysical processes.

E. The cloudiness: the state of the sky when it is covered by clouds, influences the size of the thermal amplitude and the duration of sunlight brightness, with higher values during winter, in the month of December (7.6 tenths at Nușfalău). Near the Earth's surface, the wind is characterized by short-term variations of speed, in which the surface irregularities of the earth play an important role and can amplify or diminish local turbulence. In what concerns the wind frequency on directions, in the Silvania area the calmness prevails (Nușfalău, 53.6\%).

In Zalău, during the cold season, the winds coming from the South-East prevail, being related to the channeling of air masses on Zalău Valley. In terms of wind speed, it presents low average values $(1.6 \mathrm{~m} / \mathrm{s})$ in Zalău. The integration between climate and active surface results in the formation of complex and elementary topoclimates depending on the characteristics of the active surface (altitude, aspect, slope, expressed through the received quantity of caloric energy, the duration of sunlight brightness and local air currents). The integration between the local climatic factors and the Silvania sublayer, submitted to the shaping of endogenous and exogenous factors, led to complex topoclimates, characterized by quantitative climatic indices, specific to hills and low mountains. We delineated the hills, valleys and depressions topoclimate, which, in line with the specialized literature, integrates two sublayers: low hills, under $400 \mathrm{~m}$ and high hills, over $400 \mathrm{~m}$. The topoclimate of low hills is specific to the largest part of Silvania, with the duration of sunlight brightness varying between approximately 1845 and 2175 hours/year, depending on slope and aspect. The average annual temperature is $10^{\circ} \mathrm{C}$ and precipitations vary between 550 and $650 \mathrm{~mm} /$ year.

Rain usually falls during the late spring and early summer, the wind speed is high on the watersheds (2-3 m/s) while the calmness prevails (over $50 \%$ ) in the area of valleys (Josan, 2009). The hills at the contact with Plopiş and Meseş Mountains have a topoclimate with a lower annual average temperature by $0.1-5^{\circ} \mathrm{C}$ compared to the one in the low hills, and they have higher amounts of precipitation (700 $-750 \mathrm{~mm} /$ year). In the area of contact basins and large valleys, one notices temperature inversions during winter. The cold and humid topoclimate favours agricultural activities such as animal husbandry, fruit growing and potato crops. The topoclimate of Meseș Mountains, Plopiș Mountains, Măgura Şimleului and Măgura 
Coşeiului is imposed by their low height (less than $1000 \mathrm{~m}$ ) and their position in front of the oceanic air masses (Josan, 2009). The average annual temperature descends to $8-8.5^{\circ} \mathrm{C}$, precipitation approaching $800 \mathrm{~mm} /$ year. The moderate climate, especially in Plopiş Mountains, led to permanent settlements on the watersheds, to the practice of animal husbandry, excepting some crops; all these arguments attest the integrator character of the climate and of its influence, with a double impact, in the shaping of landforms and last but not least in the development of human activities.

\section{CONCLUSIONS}

In conclusion, the influence of crionival processes on the types of land use in Silvania Mountains is due to the complex interaction between the crystalline sublayer, the sedimentary cover and the internal (lithological and tectonic factors) and external (climatic, hydrological and anthropogenic factors) geodynamic agents. Therefore Silvania Mountains have, from the point of view of the periglacial shaping, common characteristics with the Transylvanian region, with a development of the detritic perigacial layer and a predominance of the crionival sublayer. The periglacial landscape in Silvania Mountains is well represented both as regards the forms of accumulation and erosion, such as structured soils, ice tongues, forms produced by thermoclastism, nivation forms, block fields and cryo-nivation forms (gelifluctions and fluvial forms).

The most prominent marks of the periglacial shaping are found in Meseş Mountains compared to other units of Silvania due to the presence of forms of erosion and accumulation, both those developed on the slope (solifluctions and mud flows) and those resulting from gelifraction (detritus nappes). The climate change at global and regional scale increases the frequency of meteorological risk phenomena in Silvania Mountains as well as the droughts, rainfall, floods, freeze.

The intensity of crionival processes in Silvania Mountains is in line with the alternation of freeze-thaw cycles and with the maintenance of a snow layer which is deposited and maintained in the days in which the soil and air temperature is negative. It is a good insulator and protects the autumn crops during the winter, reaching a thickness of around16-17 cm (Josan, 2009). As regards the negative aspect, the snow layer can cause mechanical and chemical erosion processes, which depend on its persistence and thickness (Castiglioni, 1979).

In Silvania Mountains, the snow, through its mass, can compress the soil and vegetation if it moves, it uproots plants, agricultural crops, especially the fruit trees and the vineyards while it moves detritus masses and facilitates 
various landslide phenomena of the avalanche type especially in Meseș Mountains. The integration between the local climatic factors and the Silvania sublayer, submitted to the shaping of endogenous and exogenous factors, led to complex topoclimates, especially low hills topoclimate, favourable for the development of animal husbandry, vineyards, fruit growing and potato crops, fact which fully confirms the important agricultural potential of the Silvania area.

\section{REFERENCES}

1. Alley RB, Marotzke J, Nordhaus WD et al. (2003), Abrupt climate change. Science 299: 2005-2010.

2. Bindoff NL, Stott PA, Achuta KM et al. (2013), Detection and attribution of climate change: From global to regional. In: Stocker TF, Qin D, Plattner G-K et al. (eds) Climate Change 2013: The Physical Science Basis. Contribution of Working Group I to the Fifth Assessment Report of the Intergovernmental Panel on Climate Change. Cambridge and New York: Cambridge University Press, pp. 867-952.

3. Bond G, Showers W, Cheseby M et al. (1997), A pervasive millennial-scale cycle in North Atlantic Holocene and glacial climates. Science 278: 1257-1266.

4. Broecker WS (2003), Does the trigger for abrupt climate change reside in the ocean or in the atmosphere? Science 300: 1519-1522.

5. Broecker WS and Denton GH (1989), The role of ocean-atmosphere reorganization in glacial cycles. Geochimica et Cosmochimica Acta 53: 2465-2501.

6. Castiglioni, G.B. (1979), Geomorfologia, Ed. UTET, Torino.

7. Clark PU, Marshall SJ, Clarke GKC et al. (2001), Freshwater forcing of abrupt climate change during the last glaciation. Science 293: 283-287.

8. Clark PU, Pisias NG, Stocker TF et al. (2002), The role of the thermohaline circulation in abrupt climate change. Nature 415: 863-869.

9. Dansgaard W, White JWC and Johnsen SJ (1989), The abrupt termination of the Younger Dryas climate event. Nature 339: 532-534.

10. Fairbanks RG (1989), A 17,000-year glacio-eustatic sea level record: Influence of glacial melting rates on the Younger Dryas event and deep-ocean circulation. Nature 342: 637642.

11. Feurdean, A., Galka, M., Kuske, E., Tantau, I., Lamentowicz, M., Mulch, A., Hickșer, T. (2015), Last Millenium hydro-climate variability in Central-Eastern Europe (Northen Carpathians,Romania), The Holocene, Vol. 25(7) II79-II92,Sage.

12. Hughen KA, Overpeck JT, Lehman SC et al. (1998), Deglacial changes in ocean circulation from an extended radiocarbon calibration. Nature 391: 65-68. 
13.Josan, I., 2009, Tara Silvaniei, studiu de geografie regională, p. 7-96, 195-228. Editura Universităţii din Oradea.

14. Keigwin L.D, Jones GA, Lehman SJ et al. (1991), Deglacial meltwater discharge, North-Atlantic deep circulation, and abrupt climate change. Journal of Geophysical Research 96(C9): 16811-16826.

15. Lehman SJ, Jones GA, Keigwin LD et al. (1991) Direct evidence for early retreat of the Fennoscandian ice sheet during the last deglaciation. Nature 349: 513-516.

16. Muscheler R, Beer J, Wagner G et al. (2000), Changes in deepwater formation during the Younger Dryas event inferred from Be-10 and C-14 records. Nature 408: 567-570.

17. Paasche $\emptyset$, Løvlie R, Dahl SO et al. (2004), Bacterial magnetite in lake sediments: Late glacial to Holocene climate and sedimentary changes in northern Norway. Earth and Planetary Science Letters 223: 319-333.

18. Severinghaus J.P. and Brook EJ (1999), Abrupt climate change at the end of the last glacial period inferred from trapped air in polar ice. Science 286: 930-934.

19. Trenberth K, Overpeck J and Solomon S (2004), Exploring drought and its implications for the future. EOS 85: 27.

20.Trenberth KE (1997), Short-term climate variations: Recent accomplishments and issues for future progress. Bulletin of the American Meteorological Society 78: 1081-1096.

21.Veron, A., Novak, M., Brizova, E., Stepanova, M. (2014), Environmental imprints of climate changes and anthropogenic activities in the Ore Mountains of Boemia (Central Europa) since 13 cal.kyr BP, The Holocene,Vol.24(8) 919-931,Sage.

22. Voica, Bojar. A., Guja, O., Pelc. A, Piotrowska, Vasile, S. (2015), Bison bonasus skull from the Bihor Mountains, Romania: Isotopic and morphological investigations, The Holocene,Vol.25(7) II34-II43,Sage.

23. Wunsch, C. (2006), Abrupt climate change: An alternative view. Quaternary Research 65: 191-203. 